IX.-The Fret or Key Ornamentation in Mexico and Peru. Communicated. by Robert Philips Greg, Esq. F.S.A. F.G.S. \&c.

Read May 15, 1879.

One of the commonest as well as most characteristic forms of ornamentation on the old pottery, spindle-whorls, and even buildings of ancient Mexico and Peru, dating as far back as, or anterior even to, the Spanish conquest of America, is one very nearly allied to, if not indeed identical with, the well-known meander, Greek fret or key-pattern.

The shupes and forms of many of the earthenware jugs and pots of the same period are by no means unlike to those of the Old World, and especially to some of those of ancient Cyprus. The fylfot, however, is entirely absent as a symbol or form of ornamentation in the New World, and the cross in any form rather rare.

The herring-bone ornament is entirely wanting in Mexico and Peru, and the zig-zag ornament comparatively rare.

The circle, as might vaturally be expected amongst a people who worshipped the sun, is not uncommon. The ordinary Mexican and Peruvian forms of bronze and stone implements differ considerably in type from those of the Old World, the well-known socketed and flanged celts of the latter being entirely absent; so that, on the whole, the evidence of a very early connection between the Old and New Worlds, taken from these considerations, is not very strongly borne out, unless we may indeed consider that the key-pattern itself may have been directly introduced from the Old World.

Having paid a good deal of attention to the subject and examined the specimens from Mexico and Peru in many museums, and after pretty full examination of most of the printed works bearing on the subject, I am inclined to think that this similarity of the old Mexican and Peruvian key-pattern, as it may be called, may be merely accidental.

However that may be, its origin in the New World may pretty clearly be traced to water, of which it has evidently been considered the symbol. Curiously enough, it may have had also a similar but probably independent origin (in many 
cases at least, though perhaps not always) in the Old World. The old Mexican and Peruvian types of ornamentation are almost identical, as seen by a reference to the annexed figures.

In a work published in Mexico in 1770, entitled Historia de Nueva Hispaña escrita por su Esclarecido Conquistador Hernan Cortes, edited and added to by Don Francisco Antonio Lorenzano, Archbishop of Mexico, and containing many illustrations of a character similar to those depicted in Lord Kingsborough's great work, ${ }^{a}$ at page 2 of the Introduction, is given an engraving of a kind of calendar of the Mexican year, divided into eighteen months (of twenty days), each month having a symbolic illustration and name. That called Atemoztli, being also the first month, is called the rainy month, or mes de aguas. Fig. 1 is a copy of the picture-symbol appertaining to that month ; and it is curious that in it is clearly depicted the Greek key-pattern, as we may certainly call it, both in an angular and curved form. The brickwork, showing steps on one side, probably represents in section the end of an artificial dam or reservoir; and the pendulous material on the other side water flowing down over the top. I may here add, in explanation of this peculiar tri-form or quadri-form (as the case may be) leaf-like shaped arrangement, that, according to the text in Lord Kingshorough's work, it very commonly represents (when placed, of course, upright) the leaves of a semitropical plant, from which at certain times of the year a considerable flow of juice or moisture exudes; and hence this plant, shown with large circular drops at the end of each leaf, came, in time, to represent one of the Mexican hieroglyphic symbols for water. Fig. 2 represents the simplest form of this symbol.

What may be termed the step-pattern, see figs. $7,8,11,15,17$, generally found in combination with the key, is also an exceedingly characteristic as well as common form of ornamentation in ancient Mexico as well as Peru; whether it may have been representative in the first instance of the steps of the sacrificial altars, or of the brickwork in artificial dams or reservoirs, is not very clear; but it is not a form of ornament found in the Old World, at least certainly not in connection with the key-pattern, and thus forms an additional argument in favour of the theory that the Mexicans and the Peruvians were not indebted for the idea to the Old World. Having said this much in explanation, it is easy to see, by reference to the figures accompanying this paper, how the key-pattern or ornament, both as a separate arrangement and in continuous combination as a border or fret, came, in a country where water and rain were at certain times of the year of great importance, and where works of irrigation, \&c. were carricd on more or less extensively, to have an interest, and to be used as a frequent device on domestic pottery, water jugs, and even on public buildings.

\footnotetext{
${ }^{a}$ Antiquities of Mexico, 9 vols. imp. fol., Lond. 1831-48.
} 


\section{FRET OR KEY ORNAMENTATION IN MEXICO AND PERU}
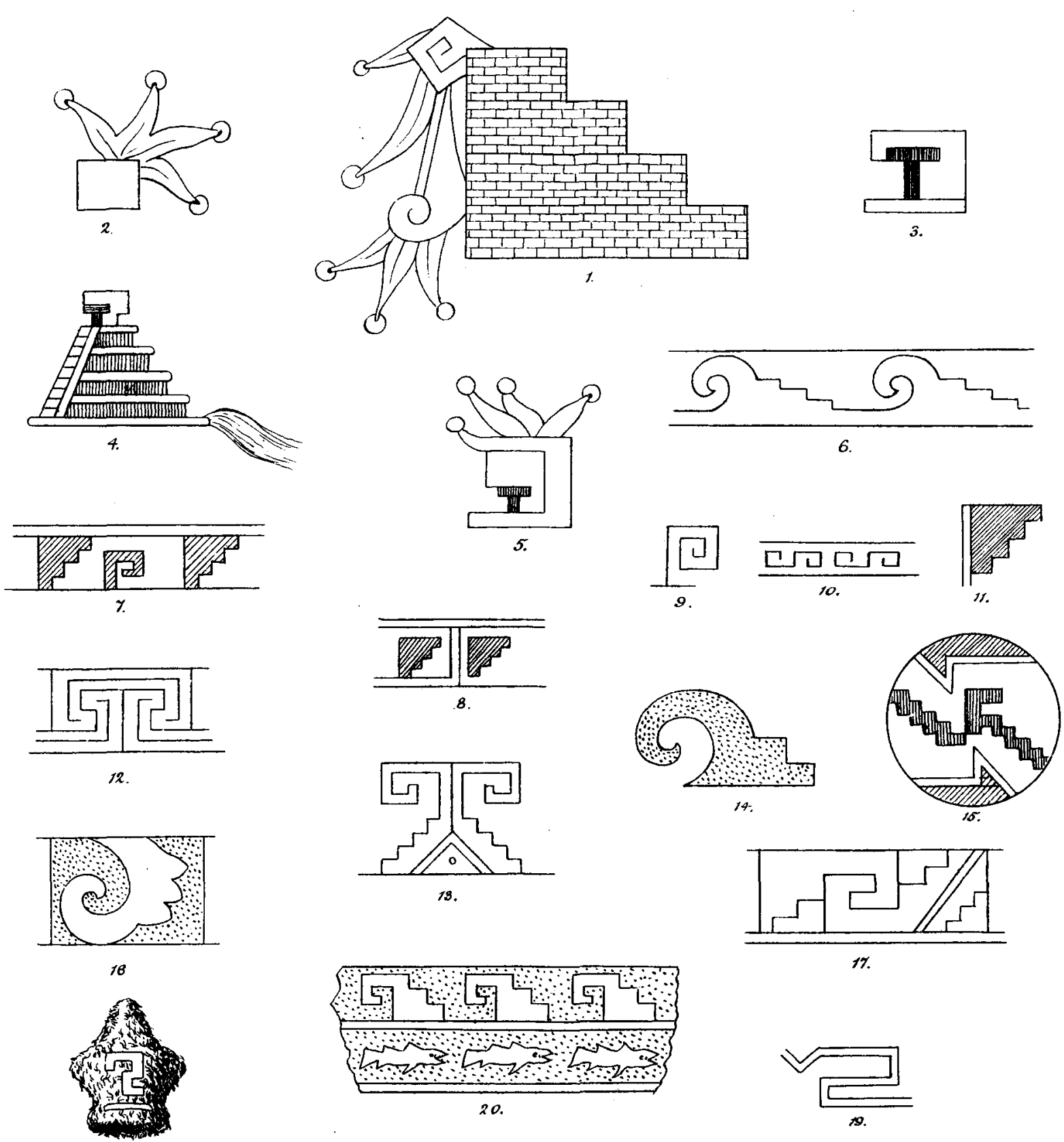

78.

\section{REFERENCES TO FIGURES.}

ligs. 1. 2. 3. 4. 5. (see Text.)

Fig. 15. Decoration on Garments. Mexico

Fig. 18. Cap or head gear, with. device.

Fig. 12. Ornamentation on an ancient stone frieze.

Mexico.
Fig. 8. On poutery, Cave dwellings Arizona.

Fig. 14. Ornamentation on a taxxa. Yucatan.

Figs 7.9.10.11.14.20. On pottery of ancient Peru Figs 6.13.16. 17. On pottery and spindle whorl. Ancient Mexico.

$$
\text { Fig. 19. On a tazza, Central America. }
$$


Fig. 20 shows the ornamentation on a Peruvian jug or vessel in my own possession, and is especially instructive as showing the natural combination of the symbol for water, placed in juxtaposition with fishes swimming immediately beneath. It is curious that a somewhat similar combination has been noticed in ancient earthenware from Magna Græcia, in which, however, the meander has a curved or wavy form. Figs. 34 and 5 are pictorial representations or symbols for house, according to Lord Kingsborough. Figs. 4 and 5 give one more the idea of being sacrificial altars; if so, there is also a curious resemblance in the shape of the quasi altar, represented in fig. 4, to the key-pattern or symbol; and in fig. 5, on the top or roof, is seen the water-giving plant of fig. 2. The key-pattern is also still found on the earthenware vessels of modern Indians in South America, who have doubtless copied from the older ware of the Peruvians of the Incas period. In North America, Professor Hayden has recently discovered pottery in the ancient cave habitations at San Juan in Arizona, on which the Mexican step-pattern just alluded to occurs. (See fig. 8.)

As is well known, the key-pattern variously modified has long been known in China and Japan, but more as an ornament than symbolic, and probably borrowed from the more western nations, or derived from the fylfot symbol, and first imported with Buddhism, B.c. 300. The same pattern in different forms not unfrequently also occurs in pottery, basket-work, and clothing, in several of the islands of the Pacific Ocean.

The history and subject of the Greek fret or key pattern is an interesting one, and one too which has scarcely yet been fully worked out; it may, in the Old World, have arisen in certain cases, as Dr. Schliemann and others have suggested, from a modification of the fylfot, with which it is found not unfrequently in some kind of combination; but generally it must be conceded, and in this I agree with Mr. Newton of the British Museum, that the ordinary meander or Greek fret was indicative at an early period of Greek art of the flowing or rippling of water. Both the Greek fret and the fylfot appear to have been unknown to the Semitic nations either as an ornament or as a symbol.

In Egypt the fylfot does not occur, and the key-pattern, I have reason to think, was employed rather as a simple geometric device than in any way symbolic, and never, that I know of, used even as a fret or border; so far as I have been able to discover, it only occurs on a painted ceiling in a tomb near Sioot, according to Wilkinson, ${ }^{2}$ B.c. 1600 , or some five hundred years before any certain archaic occurence of it elsewhere as in Greece.

It is, I believe, generally admitted or supposed that the fylfot is of early Aryan origin. Eastwards, towards India, Thibet, and China, it was adopted, in all 
probability, as a sacred symbol of Buddha; westwards, it may have spread in one form or another to Greece, Asia Minor, and even to North Germany. Originally it would appear to have been an early Aryan atmospheric device or symbol indicative both of rain and lightning, phenomena appertaining to the god Indra, subsequently or collaterally developing, possibly, into the suastika or sacred firechurn in India, and at a still later period in Greece adopted rather as a solar symbol, or converted about B.c. 650 into the meander or key-pattern. Rain and lightning as joint atmospheric phenomena would naturally correlate with water and fire; and Jupiter Pluvius and Jupiter Tonans with the eastern and earlier Indra.

This is, however, rather wandering away from the original subject of this paper, viz. the occurrence and origin of the key-pattern in ancient Mexico and Peru some three or four hundred years ago; which, as I have intimated, seems rather to have had there an independent origin, very distinctly connected with the idea of water.

Note 1.-Key-pattern or Greek fret in Egypt, on ceiling of tombs near Sioot, 1600 B.c., probably geometric and accidental; evidently not symbolizing water in any way or used as a fret or border, as 1000 years later in Greece. It had become so conventional about 2000 years ago in Greece, that there is no reason for supposing that the origin of the pattern was then known; it was more used as a continuous border pattern than in Mexico and Peru 1500 years later, in which countries, clearly, as from the evidence educed in the body of this paper, this pattern was rather employed as an actual and well-known symbol; thus giving an additional argument, in my opinion, that the same pattern had an independent origin in such widely-separated portions of the Globe, separated also by a very wide interval in time.

Note 2.-Arrow-heads.-The form of nearly all North and South American arrow-heads of stone, flint, or obsidian, including those of ancient Mexico and Peru, differs considerably in type from European or Asiatic ones. I omitted to mention this point when speaking of bronze celts. 